\title{
Chibumons: A Positive Effect on Game to Undergraduate Students
}

\author{
https://doi.org/10.3991/ijet.v15i01.11502 \\ Thanakorn Uiphanit $(\bowtie)$, \\ Suan Sunandha Rajabhat University, Bangkok, Thailand \\ thanakorn.uiessru.ac.th \\ Pattarasinee Bhattarakosol, Kwanrat Suanpong, Sompoch Iamsupasit \\ Chulalongkorn University, Bangkok, Thailand \\ Chalotorn Wongwan \\ Good Job Multimedia Company, Bangkok Thailand
}

\begin{abstract}
In the university daily life, the social skill is very important. Social skill helps students to participated and interact with people. In this paper, we present the research and development of a mobile game to develop students' social skill, 'Chibumons'. The sample group consists of 120 students, The tools used in this research were 'Chibumons', and satisfaction with game questionnaire. Statistical data analysis used in this research were average, percentage, and standard deviation. The research reveals that games can enhance the social skill of students. This consequently accretes their social skill, boosting up enjoyment, engagement, and make friendships amongst playing. Moreover, this study demonstrates that 'Chibumons' is able to promote developing social skill and motivates students in higher education.
\end{abstract}

Keywords - Social skill, undergraduate students, monsters game, video game.

\section{$1 \quad$ Introduction}

Social skill is the most important skill in any undergraduate major in most general universities. Due to that, the revolution in the Internet technology. Knowledge is become an omnipresent where any individuals with mobile devices with Internet can have access to information anywhere anytime. The social environment is change from smaller to much larger, varied, and competitive social groups. Many students are associated with loss of self-esteem, increased anxiety and depression, drops in academic performance [7], [8] and, adolescents with lower social skills. In the other hand, positive social skill are-supported, helping students adjust more quickly to communication and interactive with other people, good learning engagement and increasing academic performance [4], [6], [8], [9]. Thus, a social skill has become increasingly crucial for students daily lives. 
To refine these problems in computer network teaching, researchers interviewed 3 academic persons from university and 3 consultants from game production company who are experts in game design and psychology. They provided a several of opinions about major problems in social skill and about the main topics, the engaging and interactive nature of games, and the relative anonymity of digital environments, means students are often motivated to more fully and openly participate in game-based compared to traditional in person. Digital platforms have been shown to increase comprehension and recall of presented material over conventional instructional methods and produce greater generalization of acquired skills to real-life behavior.

Therefore, the developing social skill by digital game [10], [12] should be improved to increase social skill and there should be an innovative platform with more attraction for undergraduate students to escalate the engagement in developing social skill process [3],[9]. Moreover, The perceptions of developing social skill with games in the higher education are mainly in the positive impact such as enhanced students' enjoyment [1], [11] and fun [5], reduced student stress [9], increasing opportunities for learning by encouraging students' attention to learn difficult, contributes the learning experience by helping their colleagues[1], [17], [18].

\section{Objective}

- To design and develop a gaming application on smartphone named 'Chibumons'.

- To study students satisfaction after playing with the game.

\section{$3 \quad$ Research Framework}

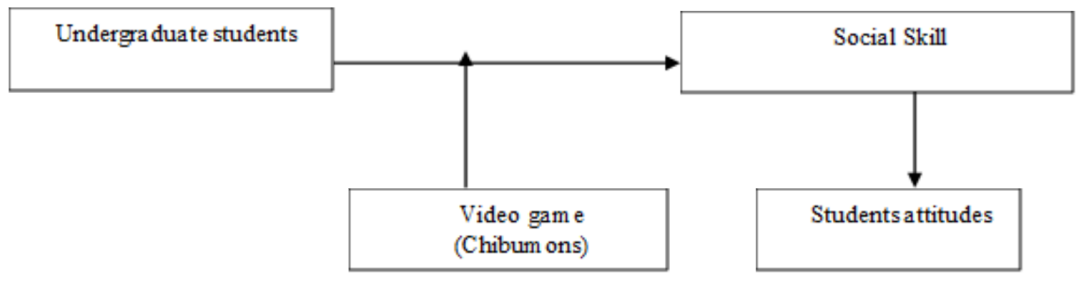

Fig. 1. The conceptual model for developing social skill with game

Accordingly, Fig.1. shows the conceptual model of this study. Our interests are to investigate the relations among the variables of the developing social skill (Chibumons), and students attitudes 


\section{$4 \quad$ Research Methodology}

\subsection{Experimental design}

In this research, an experiment was conducted on an undergraduate students at Suan Sunandha Rajabhat University to evaluate social skill of the students who participated in the interacting with game.

This game was designed based on adventure game that students assumes the role of a character within a world of fantasy (Chibumons). The game concept which is growing monster, player can play with friends and collect item to upgrade monster.

In this experiment, the processes are divided into 5 steps.

- In first step, the game is introduced to them in the meeting room.

- Secondly, students are played game.

- Thirdly, questionnaires are given to the students for inquiry of satisfaction after using the game.

- Lastly, data was analyzed to check for the effectiveness of social skill with game.

\subsection{Materials}

The participants in this study were 120 undergraduate students; consisting of 60 males and 60 females, who with the average age of 20 years old.

Chibumons game application: Chibumons is a social game aiming to aid students to develop the social skill and more enjoyable. The design and development of Chibumons is based on digital game elements and have been applied into the game application [2], [14], [15] which are fun, gameplay, rules, interactive, adaptive, problem solving, interaction, representation and story. The detail of the usage of the game elements in Chibumons is described below [10], [16], [19]

Table 1. Use of game elements in Chibumons [13]

\begin{tabular}{|c|c|c|}
\hline Game element & Question & $\begin{array}{c}\text { Objective of } \\
\text { measurement }\end{array}$ \\
\hline Fun & Is the game fun to play? & \multirow{8}{*}{$\begin{array}{l}\text { To study the degree of } \\
\text { satisfaction of students } \\
\text { who have practice digital } \\
\text { skill through the developed } \\
\text { game. }\end{array}$} \\
\hline Gameplay & $\begin{array}{l}\text { Can playing games lead to the positive effects regarding } \\
\text { study performance? }\end{array}$ & \\
\hline Rules & Are in game instructions easy to understand? & \\
\hline Interactive & $\begin{array}{l}\text { Is the in-game illustration beautiful, attractive and inter- } \\
\text { esting? }\end{array}$ & \\
\hline Adaptive & $\begin{array}{l}\text { Can the player apply the skill from the game in their daily } \\
\text { life? }\end{array}$ & \\
\hline Problem solving & Can playing games help solving problems in daily life? & \\
\hline Interaction & $\begin{array}{l}\text { Can playing games help establishing cordial interaction } \\
\text { amongst friends? }\end{array}$ & \\
\hline $\begin{array}{l}\text { Representation and } \\
\text { story }\end{array}$ & Is the in-game narration interesting and suitable? & \\
\hline
\end{tabular}


Table 2. Description of Chibumons

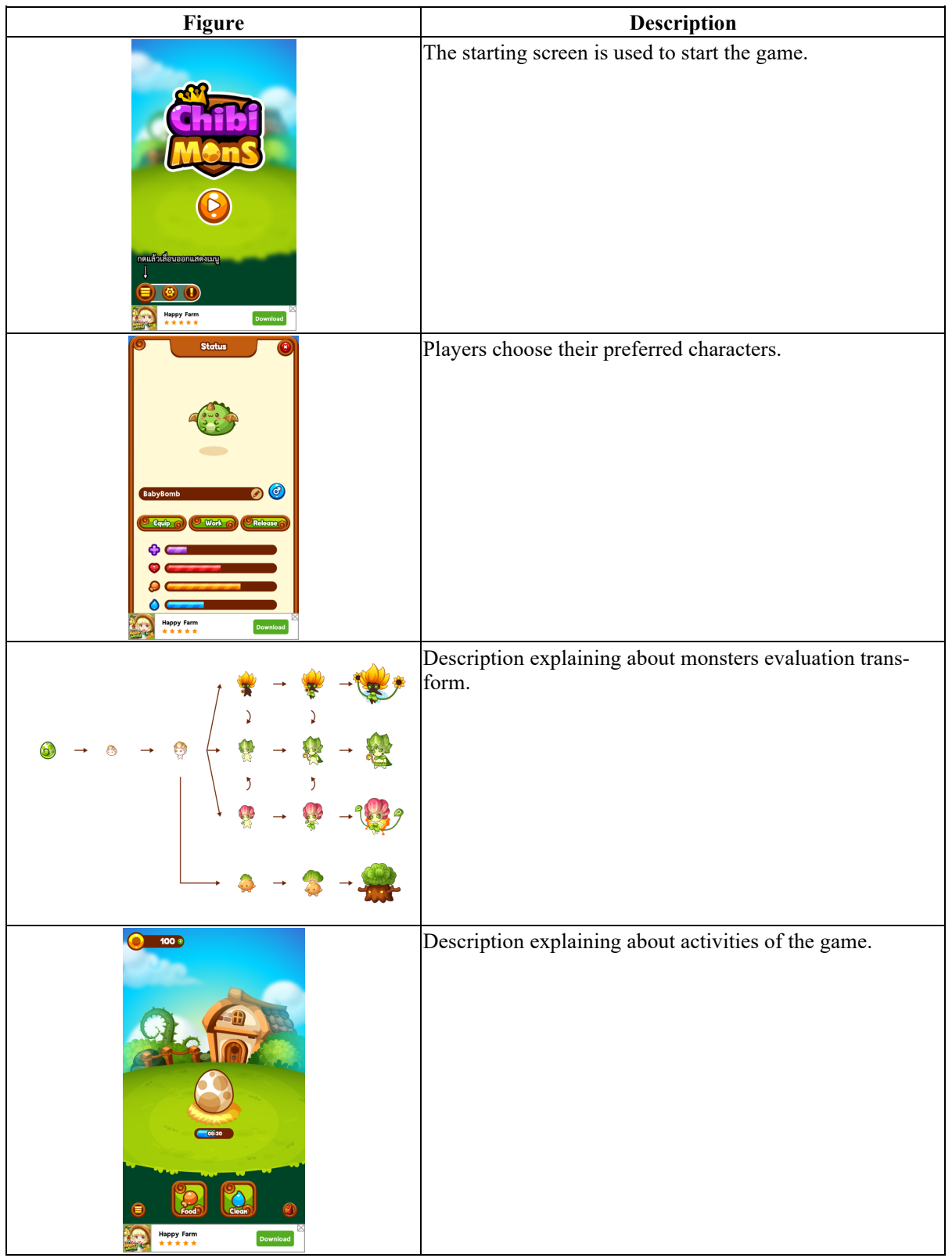




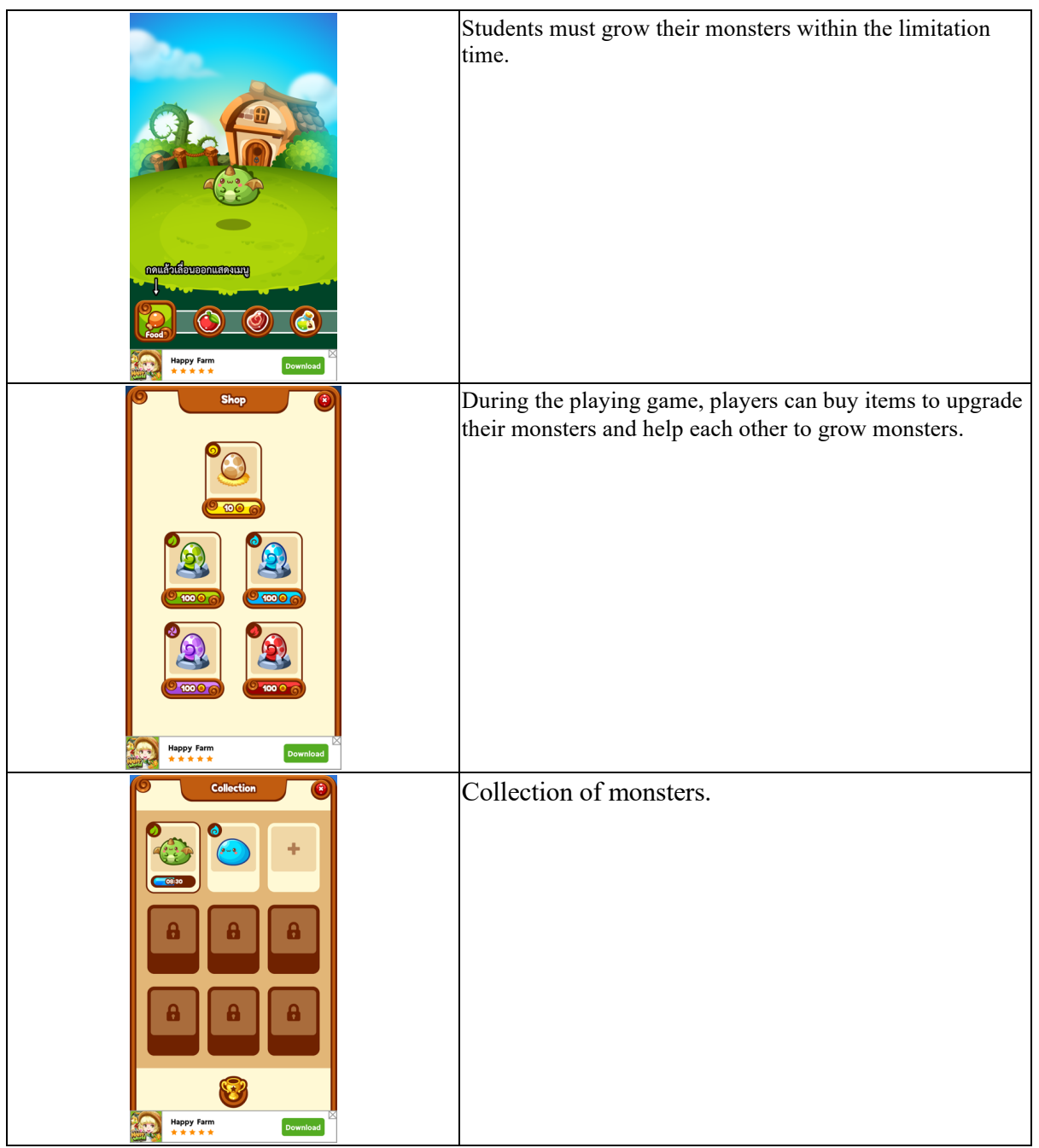

Student satisfaction questionnaire: Since The students satisfaction of playing with game is a satisfaction questionnaire aiming at studying the degree of satisfaction of students who have played through the developed game. The measurement unit in the game playing attitude is Likert scale with 5 levels with score rating of 1 to 5 , ranging from 1 meaning "strongly disagree" to 5 meaning "strongly agree".

\section{$5 \quad$ Results and Discussions}

The research results are shown that playing games can help solving problems

in studies with the highest mean value of 4.42 . The second place is playing games establish cordial interaction amongst friends with the mean value of 4.37. Followed 
by playing game is fun and the narrative in the game is interesting and suitable with the mean value of 4.2. All descriptive values of this elicitation are shown in Table 3

Table 3. Student's satisfaction after learning with the Chibumons

\begin{tabular}{|c|l|c|c|}
\hline No & \multicolumn{1}{|c|}{ Question } & Mean & S.D. \\
\hline 1 & Is the game fun to play? & 4.21 & 0.78 \\
\hline 2 & Are in game instructions easy to understand? & 4.05 & 0.62 \\
\hline 3 & Is the in game illustration beautiful, attractive and interesting? & 4.16 & 0.60 \\
\hline 4 & Can the player apply the skill from the game in their daily life? & 4.16 & 0.50 \\
\hline 5 & Can playing games help solving problems in daily life? & 4.42 & 0.60 \\
\hline 6 & $\begin{array}{l}\text { Can playing games help establishing cordial interaction amongst } \\
\text { friends? }\end{array}$ & 4.37 & 0.76 \\
\hline 7 & Is the in game narration interesting and suitable? & 4.21 & 0.71 \\
\hline
\end{tabular}

In Addition to, this information is worth focusing as it should be able to indicate that students strongly agreed that the Chibumons is able to help students to make a good friendship and game narrative will make students pay more attention in the developing skill. [15], [16], [17], [18], [19]

Additionally, the illustration in the game is beautiful, attractive and interesting, the knowledge in the game can help the player's to apply in their daily life, while the instruction in the game is easy to understand with the mean value is 4.05 . This information might lead to the assumption that students agreed that the illustration in the Chibumons is beautiful, attractive, interesting, knowledge from playing game can be applied in daily life, and the instructions in the game are easy to understand

Thus, this result is consistent with the collected data that they have positive attitude towards developing social skill with game. Moreover, the relationships among students' social skill factors are consistent and obviously be seen. Therefore, the proposed platform can support students' social skills.

Table 3 shows relationships between the improvement of students' social skill with better problem-solving since the means of these three indicators are closely high to each other. In addition, the students' relationships are closer since the game is fun, clearly instruction, beautiful illustration and the narrative of the game is interesting. Thus, Chibumons is able to help students to make a good relationship with their friends [14],[15],[16],[17]. Consequently, these results are consistent with the collected data that students have positive attitudes towards the social skill by games. Fig. 2 demonstrates the relationships among factors mentioned in Table 3. 


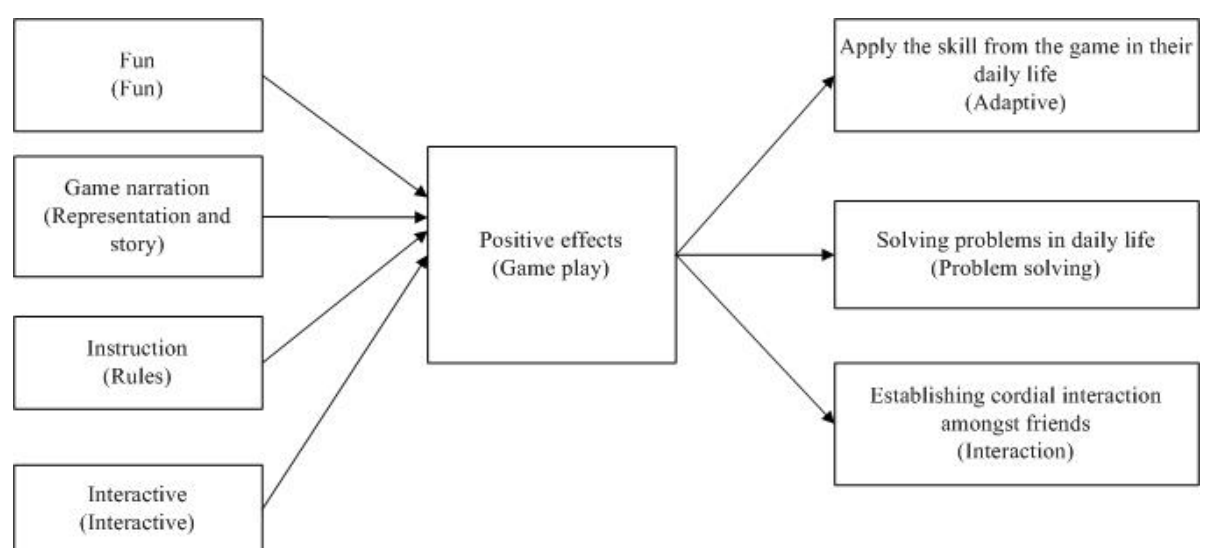

Fig. 2. Relationships among factors in Table 3

\section{Conclusion}

This research aims to develop a game to enhance the social skill. In the beginning, the script of social game were was drawn based on the theoretical contents and the software design, and implementation was performed. After finishing this development process, 120 students, at Suan Sunandha Rajabhat University tested this game. The result of this study shows that the social game "Chibumons" is an efficient tool for students to improve their social skill capabilities through enjoyment and good relationships with friends.

\section{$7 \quad$ References}

[1] Begg, M., Dewhurst, D., \& Macleod, H. (2005). Game-informed learning: Applying computer game processes to higher education. Innovate: Journal of Online Education, 1(6).

[2] Chou, Y. S., Hou, H. T., Yu, M. C., Lee, H. J., Wu, H. S., Yang, Y. T., \& Liao, Y. J. (2012). Running TommyC: Developing a Digital Adventure Game Based on Situated Learning to Promote Learners' Concepts of Earthquake Escape. In Digital game and intelligent toy enhanced learning (DIGITEL), 2012 IEEE fourth international conference on pp. 156-158. https://doi.org/10.1109/DIGITEL.2012.44

[3] Ebner, M., \& Holzinger, A. (2007). Successful implementation of user-centered game based learning in higher education: An example from civil engineering. Computers \& education, 49(3), 873-890. https://doi.org/10.1016/j.compedu.2005.11.026

[4] J. Kupersmidt and M. E. DeRosier, "How peer problems lead to negative outcomes: An integrative mediational model," in Children's peer relations: From development to intervention, J. B. Kupersmidt and K. A. Dodge, Eds., pp. 119-138, American, Washington, DC, USA, 2004. https://doi.org/10.1037/10653-007

[5] J. N. Kingery, C. A. Erdley, and K. C. Marshall, "Peer acceptance and friendship as predictors of early adolescents' adjustment across the middle school transition," MerrillPalmer Quarterly, vol. 57, no. 3, pp. 215-243, 2011.https://doi.org/10.1353/ mpq.2011.0012 
[6] J. Parker, K. Rubin, S. Erath, J. Wojslawowicz, and A. Buskirk, "Peer relationships, child development, and adjustment: Developmental psychopathology perspective," in Developmental Psychopathology, Cicchetti and Cohen, Eds., pp. 419-493, Wiley, New York, NY, USA, 2006. https://doi.org/10.1002/9780470939383.ch12

[7] J. W. Aikins, K. L. Bierman, and J. G. Parker, "Navigating the transition to junior high school: Te infuence of pre-transition friendship and self-system characteristics," Social Development, vol. 14, no. 1, pp. 42-60, 2005 https://doi.org/10.1111/j.14679507.2005.00290.x

[8] K. R. Wentzel, "Sociometric status and adjustment in middle school: A longitudinal study," Journal of Early Adolescence, vol. 23, no. 1, pp. 5-28, 2003.https://doi.org/10.1 $\underline{177 / 0272431602239128}$

[9] K. R. Wentzel and K. Caldwell, "Friendships, Peer Acceptance, and Group Membership: Relations to Academic Achievement in Middle School," Child Development, vol. 68, no. 6, pp. 1198-1209, 1997.https://doi.org/10.1111/j.1467-8624.1997.tb01994.x

[10] Kanthan, R., \& Senger, J. L. (2011). The impact of specially designed digital games-based learning in undergraduate pathology and medical education. Archives of pathology \& laboratory medicine, 135(1), 135-142.

[11] Kunnu, W., Uiphanit, T., \& Sukwises, A. (2016). The Development of Vocabulary Memorization by Using Games. International Journal of Social Science and Humanity, 6(6), 419. https://doi.org/10.7763/IJSSH.2016.V6.683

[12] M. A. Peterson, E. B. Hamilton, and A. D. Russell, "Starting well: Facilitating the middle school transition," Journal of Applied School Psychology, vol. 25, no. 3, pp. 286-304, 2009. https://doi.org/10.1080/15377900802487219

[13] M. Prensky, Digital Game-Based Learning. McGraw-Hill Trade, 2001.

[14] Matthews, J. N. (2005). Hands-on approach to teaching computer networking using packet traces. In Proceedings of the 6th conference on Information technology education, pp. 361367 https://doi.org/10.1145/1095714.1095777

[15] Pratama, L. D., \& Setyaningrum, W. (2018). GBL in Math Problem Solving: Is it Effective?. International Journal of Interactive Mobile Technologies (iJIM), 12(6), 101-111. https://doi.org/10.3991/ijim.v12i6.8658

[16] Rashid, N. A. M., Salleh, S. M., \& Noor, N. M. (2018). The Role of Game Elements in Improving Jawi Skills through a Mobile Game'G-Jawi'. International Journal of Interactive Mobile Technologies (iJIM), 12(7): 20-30.https://doi.org/10.3991/ijim.v12i7. $\underline{9636}$

[17] She, Y. X., Lin, M. H., Jong, B. S., \& Hsia, Y. T. (2013). Using Growing Pet Game in Facebook to Enhance Students' Learning Motivation: In Operating System Course. In Learning and Teaching in Computing and Engineering (LaTiCE), 2013, pp. 224-228

[18] Sung, H. Y., \& Hwang, G. J. (2013). A collaborative game-based learning approach to improving students' learning performance in science courses. Computers \& Education, 63, 43-51. https://doi.org/10.1016/j.compedu.2012.11.019

[19] Uiphanit, T., Bhattarakosol, P., Suanpong, K., \& Iamsupasit, S. (2019). Packet Warriors: An Academic Mobile Action Game for Promoting OSI Model Concepts to Learners. International Journal of Interactive Mobile Technologies (iJIM), 13(6): 41-51. https://doi.org/10.3991/ijim.v13i06.10469 


\section{Authors}

Thanakorn Uiphanit is currently a Lecturer in the Department of Information Sciences at the Suan Sunandha Rajabhat University, Bangkok, Thailand. E-mail: thanakorn.ui@ssru.ac.th

Pattarasinee Bhattarakosol is currently an Assistance Professor in the Department of Mathematics and Computer Science, Faculty of Science, Chulalongkorn University, Bangkok 10330, Thailand. E-mail: pattarasinee.b@chula.ac.th

Kwanrat Suanpong is currently a Lecturer in the Department of Commerce, Chulalongkorn Business School, Chulalongkorn University, Bangkok 10330, Thailand. E-mail: kwanrats@cbs.chula.ac.th

Sompoch Iamsupasit is currently an Associate Professor in the Faculty of Psychology, Chulalongkorn University, Bangkok 10330, Thailand. E-mail: isompoch@hotmail.com

Chalotorn Wongwan is currently a Manager in the Good Job Multimedia Companany, Bangkok Thailand. E-mail: gengsongod@gmail.com

Article submitted 2019-08-12. Resubmitted 2019-09-13. Final acceptance 2019-09-17. Final version published as submitted by the authors. 